\title{
Soviet Military City Plans Analysed: A Case Study from Israel and Denmark
}

\author{
Gad Schaffer ${ }^{\mathrm{a}}$, *, Stig Roar Svenningsen ${ }^{\mathrm{b}}$ \\ ${ }^{a}$ Tel-Hai Academic College (Israel), schaffergad@telhai.ac.il \\ ${ }^{b}$ Royal Danish Library (Denmark), stsv@ kb.dk \\ * Corresponding author
}

Keywords: Soviet, Military, Maps, City Plans, Israel, Denmark, Cartography, Military, Accuracy, Completeness

\begin{abstract}
:
This research presents a comparative analysis of historical city plans of Tel-Aviv (Israel) and Copenhagen (Denmark), secretly made by the Soviet military during the Cold War. The main aim of this research was to examine the thematic accuracy and completeness of information of the city plans, focusing on military buildings and sites.

During the Cold War, the military of the Soviet Union developed a global mapping program, which resulted in production of vast quantities of cartographic documents, including several thousand plans of cities and towns across the globe. These plans are among the most fascinating part of the cartographic legacy from the Soviet military, due to their detailed scale and rich content of both thematic and topographic information. Recent years have seen an increased focus on the cartographic legacy of the Soviet military from academia especially after the publication of the Red Atlas by Davies and Kent in 2017. Although this has improved our understanding of the cartographic enterprise of the Soviet military, several aspects have still not been thoroughly investigated. One such aspect is the thematic content in city plans in form of important objects, which constitutes an important part of the content of the plans. This is also indicated by the objects being highlighted with colours, showing their belonging to one of three categories: military, industrial and government/institutions. Moreover, the objects are represented with numbers referring to a list presenting all the objects and their map reference, which is inserted on the map or printed in a separate booklet. The prominent position of the thematic content in the city plan suggests that the information was considered vital for the Soviet Military and considerable resource must have been committed to the collection and dissemination of the thematic content. Despite this, several studies have found errors and inaccuracies of thematic information in the Soviet military city plans (Davies and Kent 2018; Kent, Davis, Davies 2019; Whyte 2020; Svenningsen 2020). While several studies have analysed the content of individual city plans, comparative studies of city plans are yet limited to analysis of the use of symbology (Davis 2018). A limiting factor in relation to undertaking comparative analysis is the need for detailed information about the cities mapped by the Soviets, which include the ability to read local sources and access information. However, comparative studies of the thematic content of Soviet city plans might contribute to the wider debate about the purpose and nature of the Soviet military mapping program (Kent and Davies, 2013).
\end{abstract}

In this research we conduct a comparative study of Soviet military city plans of Tel-Aviv in Israel and Copenhagen in Denmark. During the Cold War (1947 - 1991) Denmark and Israel were both under the Western Bloc coalition guided by the USA opposing the East Block led by the USSR. Nonetheless, while Denmark was a full NATO member, Israel was just an ally in the Western Bloc coalition. Moreover, Denmark's location in North Europe is geographically very close to the USSR borders, unlike Israel which is located further away in the Middle East. From a military and geostrategic point of view, for the Soviets, Denmark was more important than Israel. These differences make the comparison between the two countries interesting. Given the geostrategic position of Denmark, one would expect the Soviet city plans of Denmark to be more precise, up to date, have more details, and show broader military attributes than the city plans of Israel?

There are several Soviet city plans of different cities in Denmark (6) and Israel (7). In this research we have decided to focus on the two major and most important cities at that time - Copenhagen, the capital city of Denmark and Tel-Aviv, while not the capital city of Israel, was the largest city and was also an international, cultural, economic, and political centre. The Tel-Aviv soviet plans are at a scale of 1:10,000 and 1:25,000 for Copenhagen. The Soviet plans represent buildings, streets, roads and more interestingly military sites, government buildings and industrial areas. In this research the focus will be on the military sites. The Tel-Aviv plan covers the Greater area of Tel-Aviv and is composed of six sheets compiled in 1980 and printed in 1985 in Tashkent. It includes 161 important objects. The city plan of Copenhagen covers parts of the Greater Copenhagen area and is made up of two separate sheets compiled in 1982 and printed in 1985 in Leningrad. It includes 298 important objects. 
The research consists of four different stages and uses diverse materials. First, to examine the geographic accuracy of the city plans, all the Soviet plans will be georeferenced to present-day satellite imagery or topographic maps using the ArcGIS software program. Second, each military site on the plans will be marked by digitizing them. In the third step, the shape of the buildings in these sites will be compared to other historical maps and present-day satellite imagery in order to examine the accuracy of the features on the Soviet plans. In the fourth step of this research, we will try to examine whether the military sites on the Soviet city plans were indeed military sites. For this purpose, we will use a variety of sources which will include, local maps, archival material, and internet material.

\section{References}

Davies, J., \& Kent, A. J. (2020). "Red Star to Red Lion: The Soviet Military Mapping of Oxford”. In A. J. Kent, S. Vervust, I. J. Demhardt, \& N. Millea (Eds.), Mapping Empires: Colonial Cartographies of Land and Sea (pp. 143-158). Springer International Publishing.

Davies, J., \& Kent, A. (2017). The Red atlas: How the Soviet Union secretly mapped the world. University of Chicago Press.

Davis, M. (2018) A Cartographic Analysis of Soviet Military City Plans, PhD Thesis, Canterbury Christ Church University.

Kent, A. J. (2021) “The Soviet military 1:10,000 city plan of Dover, UK (1974)”. International Journal of Cartography, 7(2): $245-251$.

Kent, A. J., Davis, M., \& Davies, J. (2019). “The Soviet mapping of Poland - a brief overview.” Miscellanea Geographica, 23(1), 5-15.

Kent, A. J., \& Davies, J. M. (2013). "Hot geospatial intelligence from a Cold War: The Soviet military mapping of towns and cities." Cartography and Geographic Information Science, 40(3), 248-253.

Svenningsen, S. R. (2020). "Den sovjetiske militære kortlægning af Danmark under Den Kolde Krig: En del af det verdensomspændende sovjetiske militære kortlægningsprogram.” Fra Krig og Fred - Dansk Militærhistorisk Kommissions Tidsskrift, 2020, 141-176.

Whyte, B. (2020). “Where's my Embassy, Comrade?': An examination of the 1981 Soviet military city plan of Canberra." The Globe, 87, 38-50. 